\title{
Risk Factors of Hipertension and Diabetes Mellitus on COVID-19 Mortality
}

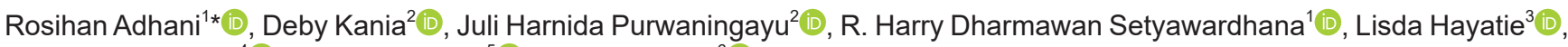 \\ Triawanti Triawanti ${ }^{4}$, Husaini Husaini ${ }^{5}$ D, Syamsul Arifin $^{6}$ (D) \\ ${ }^{1}$ Department of Dental Public Health, Faculty of Dentistry, Lambung Mangkurat University, Banjarmasin, Indonesia; ${ }^{2}$ Department \\ of Biomedicine, Faculty of Dentistry, Lambung Mangkurat University, Banjarmasin, Indonesia; ${ }^{3}$ Department of Parasitology, \\ Faculty of Medicine, Lambung Mangkurat University, Banjarbaru, Indonesia; ${ }^{4}$ Department of Biochemistry and Biomolecular, \\ Faculty of Medicine, Lambung Mangkurat University, Banjarmasin, Indonesia; ${ }^{5}$ Department of Public Health Science, Faculty of \\ Medicine, Lambung Mangkurat University, Banjarbaru, Indonesia; ${ }^{6}$ Department of Healthy Administration and Policy Magister \\ Public Health, Faculty of Medicine, Lambung Mangkurat University, Banjarbaru, Indonesia
}

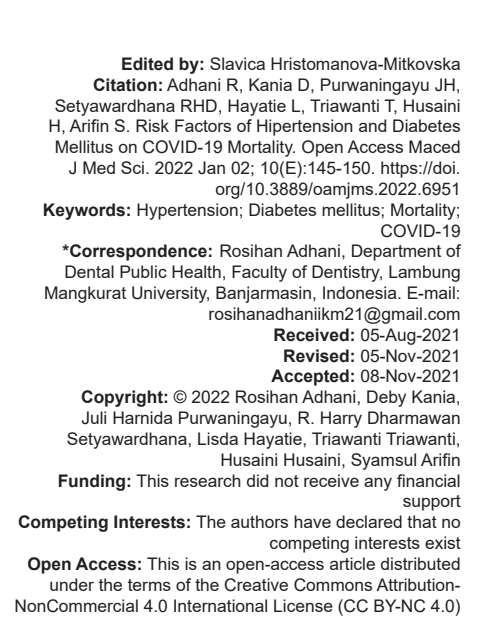

\section{Abstract}

BACKGROUND: Case fatality rate (CFR) for global COVID-19 infections since June 14, 2021 was $2.17 \%$, while CFR for Southest Asia were $1.39 \%$. CFR in Indonesia so far were $3.05 \%$. This missed from the target of the 2005-2025 RPJMK (Middle long run national health planning) in achieving healthy Indonesia; handling epidemic diseases must be able to reduce the mortality rate below $1 \%$. The government issued the Decree of the Minister of Health Republic of Indonesia No. HK.01.07/Menkes/2020 concerning the Determination of Vaccine Types for the Management of COVID-19. However, the existence of this policy did not reduce the mortality rate trend of COVID-19 in Indonesia. Hypertension and diabetes mellitus were the larger risk factors for COVID-19 mortality. Guo et al. 2020 found comorbid COVID-19 sufferers were hypertension $24.7 \%$ and diabetes mellitus $21.2 \%$. However, Mikami et al., 2020 stated differently that hypertension and diabetes mellitus were not at risk of COVID-19 mortality

AIM: Objective of this study was to estimate the average tendency of hypertension and diabetes mellitus as risk factor for COVID-19 mortality.

METHODS: Meta-analysis with 16 articles analyzed by RevMan 5.4

RESULTS: pHR for hypertension was $1.15(95 \% \mathrm{Cl} 1.00$ - 1.32) and diabetes mellitus was $1.21(95 \% \mathrm{Cl} 1.13-1.29)$. CONCLUSION: Hypertension had risk 1.15 times and diabetes mellitus had risk 1.21 times for COVID-19 mortality.

\section{Introduction}

Globally, improving health status was the goal of health development because anything that caused health problems to the global society will cause huge economic losses for the country, and every effort to improve health status society also means investment for the development of the country. Global infections of COVID-19 since June 22, 2021 had been reported around $178,503,429$ cases and caused the deaths of around $3,872,457$ people (Case fatality rate [CFR] $2.17 \%$ ), in the Southeast Asia region as many as $34,182,792$ confirmed cases of COVID-19 with a death toll of 474,870 . people (CFR $1.39 \%$ ) [1].

The spread of emerging infection cases in Indonesia were one of the problems Indonesia currently facing. COVID-19 cases in Indonesia since June 22, 2021 as many as $1,792,528$ positive cases and as many as 54,662 people died with a CFR of $3.05 \%$, Indonesia has the highest CFR value in Southeast Asia [1], [2]. This misses the target in the 2005-2025 RPJMK in achieving a healthy Indonesia; handling epidemic diseases in health care facilities must be able to reduce the mortality rate below 1\% [2]. This needs to be a concern regarding factors that can increase the risk of death from Covid-19 as an epidemic that the world were currently facing.

Bennett et al. (2017) revealed that the risk factor for death due to infection was the presence of comorbidities. About $73 \%$ of COVID-19 sufferers had comorbid diabetes (20\%), hypertension (15\%), and cardiovascular disease (15\%). This was supported by the observations of Guo et al., 2020 which found that the most comorbid in patients with COVID-19 was hypertension as much as $24.7 \%$, accompanied by diabetes mellitus as much as $21.2 \%$. According to scientific studies by Zhou et al., 2020 stated that of 191 patients, 91 (48\%) patients had comorbidities and the most was hypertension as much as $30 \%$, followed by diabetes as much as $19 \%$ and $8 \%$ coronary heart 
disease. Albitar et al., 2020 states that old age in men, hypertension and diabetes mellitus were risk factors for death in COVID-19 patients [3], [4], [5], [6].

The research of Wu et al., (2020) through the hazard ratio value stated that patients with hypertension had a risk of 3,72 times compared to those without hypertension, and patients with diabetes mellitus have a risk of 3.30 times compared to those without diabetes mellitus. However, different things were revealed in the study of Mikami et al., (2020) which stated that the hazard ratio values for COVID-19 patients with hypertension and diabetes mellitus were 0.91 and 0.92 (hazard ratio value $<1$ ) which means hypertension and diabetes mellitus was not at risk of causing death from Covid-19. Supported by Ouchetto and Bourhanbour (2020) stated that comorbid diabetes was not too closely related to death from COVID-19 [7], [8], [9]

Based on the description of the problem and the research gap, researchers were interested in conducting a meta-analysis related to comorbidities and COVID-19 mortality.

\section{Methods}

This was a systematic review and metaanalysis which was conducted using secondary data. Meta-analysis was one form of research, using data from other existing studies (secondary data) with quantitative methods. The data were processed in the meta-analysis and used to make statistical conclusions.

Search for articles through systematic and comprehensive databases PubMed, Science direc, and JAMA. Search was done by following keywords "COVID-19","Coronavirus", "SARS-CoV-2", "Mortality", "CFR", "Death", "Comorbidity", "Hipertension", and "Diabetes Melitus". Identify research questions used
SPIDER (Sample, (Phenomenon of Interest, Design, Evaluation, Research Type).

Sampling collection used purposive sampling as many as 16 articles. The inclusion criteria in this study were reputable articles in the database of articles published no more than the last 5 years, articles with confirmed COVID-19 patients, articles with cohort studies, articles presenting adjusted hazard ratio, and confidence interval numbers. The exclusion criteria for this research were articles that still in preprint form and descriptive articles.

The search followed the PRISMA protocol by assessing the quality of the articles using the Newcastle-Ottawa scale instrument. Data analyses using Review Manager 5.4 software. The results of this software analysis were the results of heterogeneity, pooled hazard ratio, and overall effect.

Heterogeneity test was conducted to determine the analysis model, namely the fixed effect model (FEM) and the random effect model (REM).

\section{Results}

Based on PRISMA, from 3 databases (PubMed, Science direct and JAMA) obtained 313.458 scientific articles related to research titles. After screening, 7,631 articles were obtained. A total of 138 full text articles and adjusted for comorbidities-related inclusion criteria with Covid-19 deaths; 16 articles were analyzed using the PRISMA protocol.

Figure 1 showed the forest plot from the results of data analysis from 11 research articles on the relationship of comorbid hypertension with death from COVID-19. The analysis used a REM, because the results of the analysis show that the research variation was heterogeneous ( $p$ Chi-square $=0.0003 ; 12$ value $=69 \%$ ). The pooled

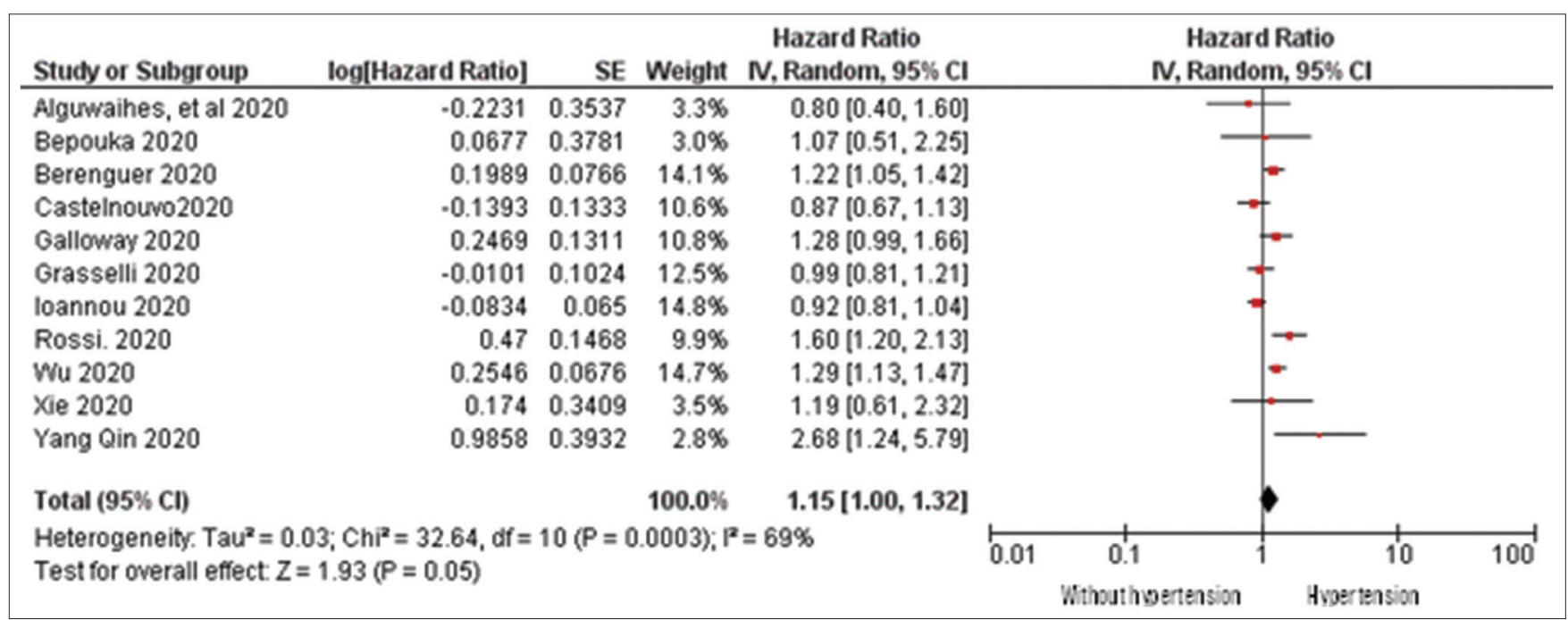

Figure 1: Forest plot correlation between hypertension with COVID-19 mortality 
hazard ratio value was 1.15 with a $95 \%$ confidence interval of 1.00-1.32 so it could be concluded that COVID-19 patients with comorbid hypertension will be at risk of 1.15 times dying due to COVID-19 compared to patients without comorbid hypertension.

Figure 2 showed the funnel plot with publication bias, indicated by the asymmetric distribution of plots. The number of plots on the left was 5 and on the right there were 5 plots and 1 plot touched the vertical line. Figure 3 showed the results of data analysis from 13 research articles on the relationship between comorbid diabetes mellitus and COVID-19 mortality. The analysis used a FEM, because the research was homogeneous ( $p$ Chi-square $=0.30 \mathrm{I} 2$ value $=14 \%$ ). The results of data analysis showed that there was a significant relationship between comorbid diabetes mellitus and COVID-19 mortality with the overall effect test value smaller than 0.05 ( $p<0.00001)$ so that the results of statistical metaanalysis for comorbid diabetes mellitus with COVID-19 mortality showed a meaningful correlation. The pooled hazard ratio value was 1.21 with a $95 \%$ confidence interval of 1.13-1.29 so it could be concluded that patients with comorbid diabetes mellitus would increase the risk or tend to be 1.21 times more likely to dying from COVID-19 than patients without diabetes mellitus.

Figure 4 showed the results of the funnel plot which shows publication bias, indicated by the asymmetrical distribution of plots on the right and left of the vertical line with unequal spacing between plots. The number of plots on the left was 4 and on the right there were 6 plots and 3 plots located in the middle of the vertical line.

\section{Discussion}

The heterogeneity in this study was related to the differences in the population of the research subjects. The funnel plot shows publication bias [10]. According

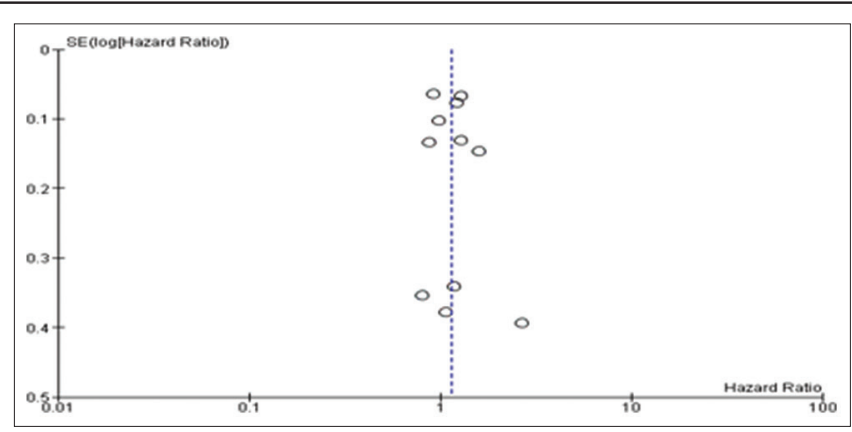

Figure 2: Funnel plot correlation between hypertension with COVID19 mortality

to Sterne et al., (2011) if there was no bias, the plot will form a symmetrical distribution. Asymmetry may occur due to overestimation of treatment effects in smaller studies with lower methodological quality [11], [12].

According to Alfhad et al., (2020) the severity of COVID-19 in hypertensive patients was associated with the use of angiotensin-converting enzyme (ACE) inhibitor drugs and angiotensin II receptor blockers (ARBs), because the use of these drugs can regulate ACE2 receptors. Indirectly, COVID-19 infection can worsen the condition of people with hypertension. COVID-19 that attacks ACE2 can eliminate the role of ACE2 in the renin-angiotensinaldosterone system (RAAS) system. The reduced effectiveness of ACE2 can inhibit the formation of angiotensin [1], [2], [3], [4], [5], [6], [7] which was one of the compounds in the feedback system of the RAAS. This inhibition of ACE2 can also lead to accumulation of angiotensin II which has a vasoconstrictive effect. This results in no homeostasis in the blood pressure system and makes blood pressure conditions continue to be at high pressure. Efforts to take ACE inhibitors and ARBs for the treatment of hypertension can also make patients more susceptible to COVID-19 infection. This was due to an increase in the expression of ACE2 caused by the consumption of this class of drugs. The increase in ACE2 can make it easier for COVID-19 to bind to target cells because the number of receptors increases

\begin{tabular}{|c|c|c|c|c|c|c|c|c|c|}
\hline \multirow{2}{*}{$\begin{array}{l}\text { Study or Subgroup } \\
\text { Alguwaihes } 2020\end{array}$} & \multirow{2}{*}{$\frac{\log [\text { Hazard Ratio] }}{0.1823}$} & \multirow{2}{*}{$\begin{array}{r}\text { SE } \\
0.275\end{array}$} & \multirow{2}{*}{$\frac{\text { Weight }}{1.5 \%}$} & \multirow{2}{*}{$\begin{array}{c}\begin{array}{c}\text { Hazard Ratio } \\
\text { N, Fixed, 95\% CI }\end{array} \\
1.20[0.70,2.06]\end{array}$} & \multicolumn{5}{|c|}{$\begin{array}{l}\text { Hazard Ratio } \\
\text { IV, Fixed, } 95 \% \mathrm{Cl}\end{array}$} \\
\hline & & & & & & & & & \\
\hline Bepouka 2020 & 0.27 & 0.407 & $0.7 \%$ & $1.31[0.59,2.91]$ & & & & & \\
\hline Castelnuovo 2020 & 0.6931 & 0.2823 & $1.4 \%$ & $2.00[1.15,3.48]$ & & & & & \\
\hline Galloway 2020 & 0.2151 & 0.1359 & $6.2 \%$ & $1.24[0.95,1.62]$ & & & to & - & \\
\hline Grasseli 2020 & 0.1655 & 0.0794 & $18.2 \%$ & $1.18[1.01,1.38]$ & & & $=$ & & \\
\hline loannou 2020 & 0.1222 & 0.0675 & $25.2 \%$ & $1.13[0.99,1.29]$ & & & $F$ & & \\
\hline Li 2020 & 0.571 & 0.2381 & $2.0 \%$ & $1.77[1.11,2.82]$ & & & & & \\
\hline Magro 2021 & 0.1906 & 0.0872 & $15.1 \%$ & $1.21[1.02,1.44]$ & & & - & - & \\
\hline Natchigall 2020 & 0.0198 & 0.1569 & $4.7 \%$ & $1.02[0.75,1.39]$ & & & 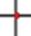 & & \\
\hline Rossi 2020 & 0.47 & 0.1912 & $3.1 \%$ & $1.60[1.10,2.33]$ & & & & - & \\
\hline Wu 2020 & 0.239 & 0.0922 & $13.5 \%$ & $1.27[1.06,1.52]$ & & & - & - & \\
\hline Yehia 2020 & 0.077 & 0.1222 & $7.7 \%$ & $1.08[0.85,1.37]$ & & & - & & \\
\hline Zhang 2020 & 1.0613 & 0.5364 & $0.4 \%$ & $2.89[1.01,8.27]$ & & & & & \\
\hline Total $(95 \% \mathrm{Cl})$ & & & $100.0 \%$ & $1.21[1.13,1.29]$ & & & 1 & & \\
\hline \multirow{2}{*}{\multicolumn{4}{|c|}{$\begin{array}{l}\text { Heterogeneity: } \mathrm{Chi}^{2}=14.01, \mathrm{df}=12(P=0.30) ;\left.\right|^{2}=14 \% \\
\text { Test for overall effect: } Z=5.54(P<0.00001)\end{array}$}} & & $\stackrel{\circ}{0.01}$ & 0.1 & 1 & 10 & 100 \\
\hline & & & & & & Without Dia & & Diabetes Mell & \\
\hline
\end{tabular}

Figure 3: Forest plot corelation between diabetes mellitus with COVID-19 mortality 
so that patients who are taking these drugs were more susceptible to infection with COVID-19 [13], [14].

Berenguer et al., (2020) which states that there was a relationship between hypertension and COVID-19 mortality assumed that patients with hypertension would experience endothelial organ damage and susceptible to reacted with COVID-19 infection. Rossi et al. (2020) assumed that the difficulty in all COVID-19 patients entering self-quarantine effective for comorbid patients. Wu et al. (2020) assumed that death from COVID-19 related to hypertension caused by hypertension as a comorbid will result in severe and acute respiratory disorders that will worsen in a short time and die from multiple organ failure. According to research Yang et al., (2020) found that the leukocyte count in the hypertension group was significantly lower than in the nonhypertensive group, and the same was true for critically ill patients. The poor outcome in the hypertensive group was related to decrease immune function caused by decreased lymphocytes. Hypertension and other chronic diseases result in some common characteristics, such as a proinflammatory state and a weakened innate immune response. Therefore, the body cannot effectively control the virus in its early stages, which causes the severity of illness in COVID-19 patients and can result in death. COVID-19 patients with hypertension showed a decrease in CD3, CD4, and CD8 T cells compared to healthy patients. Receptor II blocking drugs could significantly increase the expression of ACE2. ACE2 was a SARS-CoV-2 receptor in humans which, when increased due to ribonucleic acid expression, can exacerbate disease [8], [15], [16], [17].

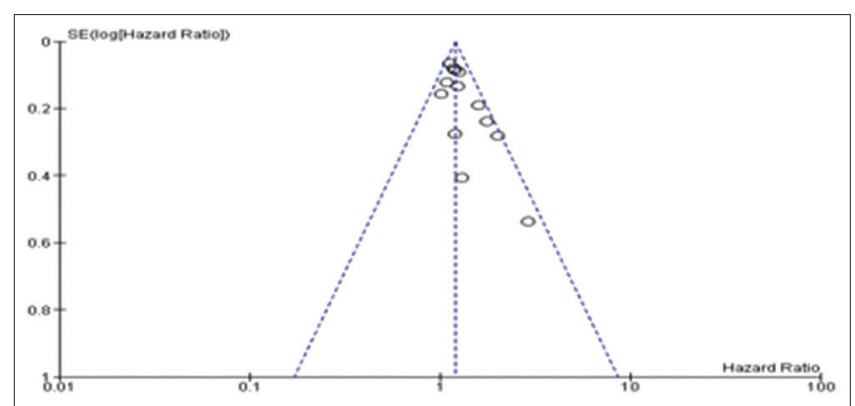

Figure 4: Funnel plot correlation between hipertension with COVID-19 mortality

According to Alguwaihes et al., (2020) which states that hypertension was not related because the use of -blockers in hypertensive patients can be beneficial, by reducing pulmonary vascular flow, which ultimately reduces further damage to lung injury due to COVID-19 infection in patients who suspected ARDS or common complications admitted to the intensive care unit (ICU). According to loannou et al., (2020) there were several conditions that were not significantly associated with death, because the severity of a comorbid condition also affects the presence of death compared to the presence or absence of the comorbid condition. The results of the research by Xie et al., (2020) stated that the data in their research were obtained in emergency situation operations under crisis conditions, like many other contemporary studies from Wuhan. Therefore, the completeness of data recording (especially at the time of hospital admission) was less than optimal and causes results that do not affect the hypertension variable as a risk factor [18], [19], [20].

The mechanism diabetes increased patients with COVID-19 mortality was based on mechanisms of chronic systemic inflammation, increased coagulation activity, impaired immune response, and the potential for direct damage to the pancreas by COVID-19. Changes in ACE2 receptor expression, dysregulation of the number and activity of immune cells, alveolar dysfunction, endothelial dysfunction, and increased systemic coagulation. Diabetes facilitate COVID-19 entry into cells and dysregulated the inflammatory response. Diabetes found in elderly individuals and/ or individuals with other comorbidities, such as hypertension, also increases the morbidity and mortality of these patients [21].

The assumption of Zhang et al. (2020) who found that diabetes mellitus was associated with COVID-19 mortality stated that diabetes would affect the homeostasis of the proinflammatory immune response toward helper $\mathrm{T}$ cells 1 (Th1) and T17 cells and a decrease in regulatory $T$ cells. Immune dysfunction in diabetes after infection had been reported for a wide variety of immune cells, not only macrophages, monocytes and CD4+ T cells. Total T-cell counts, CD4+ and CD8+ were substantially reduced and functionally depleted. Laboratory results in people with COVID-19 and diabetes mellitus showed a higher increase in leukocytes and neutrophils in those without diabetes mellitus, so that diabetes was more susceptible to pathogens after viral infection due to lower immune function [22]. Li et al., (2020) also mentioned in their research that there was a hyperglycemia conditions associated with diabetes were associated with corticosteroid therapy. Patients with COVID-19 were reported to experience damage to the islets of Langerhans so that high-dose corticosteroid therapy could have an impact on the severity of their infectious disease. A significant correlation between diabetes and the risk of COVID-19 mortality was more susceptible in women than in men [23].

The assumption of loannou et al. (2020) stated that there was no correlation between diabetes mellitus and COVID-19 mortality. It was said that this correlation was not because of the presence or absence of comorbidities suffered by COVID-19 patients, but the severity of a comorbid condition also affects the presence of death compared to the presence or absence of these comorbid conditions. Patients, with comorbid diabetes mellitus, that were controlled so that their comorbid conditions did not aggravate COVID-19 infection [19]. 
Nachtigall et al. (2020) conducted in Germany stated that there was no correlation between diabetes mellitus and COVID-19 mortality, this was assumed because the health infrastructure in Germany was comparable to hospital beds and adequate ICU bed capacity. Furthermore, the ability to test COVID-19 in Germany compared to other countries had increased in patient identification and preparedness in Germany to avoid outbreaks of COVID-19 infection was able to isolate patients, even those with comorbidities or older patients with symptomatic symptoms and being treated in the hospital. The population for Nachtigall's research was also still limited to describe the German population in general, especially the population that used health insurance in Germany. The most of the German population who registered for insurance had a higher prevalence of chronic diseases such as hypertension, diabetes, and coronary artery disease, so the researchers assumed low mortality due to comorbidities because most of the population with high comorbidities and enrolled in insurance were not included in this study [24].

Each variable does not only directly affect the independent variables, there were always confounding variables that were also involved in the occurrence of effects on the independent variables, so the researcher used adjusted hazard ratio data through a multivariate test, because these data had been adjusted for other confounding variables. All covariates present in all data should be identified by logistic regression analysis.

In relation to the current pandemic faced by Indonesia, the government has issued a policy regarding the Health Protocol for the Community in Public Places and Facilities in the Context of Preventing the Control of COVID-19 which is summarized in the Decree of the Minister of Health of the Republic of Indonesia No. HK. 01.07/Menkes/382/2020. According to the researcher, the policy had not yet regulated in technical detail the protocol for vulnerable groups such as the elderly and patients with comorbidities. The expected community behavior in Healthy Indonesia 2025 is proactive behavior to maintain and improve health; to prevent the risk of disease, according to the policy of the Indonesian Ministry of Health No. HK.02.01/MENKES/12/2021 regarding Capacity Building for COVID-19 Patient Care, the government was obliged to ensure the implementation of this policy related to the availability of health care facilities and facilitating other vulnerable groups (patients with comorbidities) to continue to be able to carry out and develop well in achieving the goals of an independent and productive society.

Decree of the Minister of Health of the Republic of Indonesia No. HK. 01.07/Menkes/382/2020 concerning Health Protocols for the Community in Public Places and Facilities in the Context of Preventing COVID-19 Control, it was necessary to develop a strategy that was formulated to be $(5 T+4 M)-3(C S P)$. The strategy is in the form of increasing 5T (Testing, Tracking, Treatment, Tracing and Teamwork), increasing 4M (Masked,
Maintain to washing hands with soap, Maintain a minimum distance of 1 meter, Maintain body immunity). The strategy also mentions 3 controls (CSP), namely 3C (close contact, crowds, controls for mortality), 3S (suspect, set for proper air circulation, set for inadequate health facilities/infrastructure) and 3P (probable, prevent for high movement, preside to monitoring people during quarantine/low insulation) [2], [25], [26].

One of the efforts to prevent the occurrence of COVID-19 infection for high-risk groups (elderly, people with comorbidities, and men) has been formulated by the government in that Decree of the Minister of Health concerning Determination of Vaccine Types for Management of COVID-19. This group vulnerable to COVID-19 infection needs to get socialization about vaccines and prioritize getting vaccines. However, with this policy, it was hoped that it would not reduce efforts to prevent COVID-19 control in the field because health workers will instead focus more on distributing vaccines to the community and result in $5 \mathrm{~T}$ efforts (Testing, Tracking, Treatment, Tracing, and Teamwork) being no longer a priority. This can be proven by the declining trend of COVID-19 cases since the vaccine was distributed to the public, but the trend has jumped again. The decline in the trend of cases could be caused by a lack of testing and tracking and tracing efforts in the field so that positive cases were not recorded in the data for the COVID-19 handling group in Indonesia and eventually the trend fell. Testing efforts are expected to still reach a ratio of 1:1000 population per week [2], [25].

\section{Conclusion}

Hypertension had risk 1.15 times and diabetes mellitus had risk 1.21 times for COVID-19 mortality.

\section{References}

1. World Health Organization. Coronavirus disease (COVID-19) Weekly Epidemiological Update and Weekly Operational Update. Geneva: World Health Organization; 2021. Available from: https:// www.who.int/emergencies/diseases/novel-coronavirus-2019/ situation-reports/ [Last accessed on 2021 Jun 22].

2. Kemenkes Republik Indonesia. Situasi Terkini Perkembangan Coronavirus Disease (COVID-19). Infeksi Emerging; 2020. Available from: https://covid19.kemkes.go.id/situasi-infeksiemerging/info-corona-virus/situasi-terkini-perkembangancoronavirus-disease-covid-19-05-november-2020/\# X6hyQyNS82w [Last accessed on 2021 Jun 22].

3. Guo W, Li M, Dong Y, Zhou H, Zhang Z, Tian C, et al. Diabetes is a risk factor for the progression and prognosis of Covid-19. Diabetes Metab Res Rev. 2020;36:e3319. https://doi.org/ 10.1002/dmrr.3319

PMid:32233013 
4. Mikami T, Miyashita $H$, Yamada T, Harrington $M$, Steinberg $D$, Dunn A, et al. Risk factors for mortality in patients with COVID-19 in New York city. J Gen Intern Med. 2020;36(1):17-26. https:// doi.org/10.1007/s11606-020-05983-z

PMid:32607928

5. Bennett JE, Dolin R, Blaser MJ. Infectious Disease Essentials. United Kingdom: Elsevier; 2017.

6. Zhou F, Yu T, Du R, Fan G, Liu Y, Liu Z, et al. Clinical course and risk factors for mortality of adult inpatients with COVID-19 in Wuhan, China: A retrospective cohort study. Lancet 2020;395(10229):1054-62. https://doi.org/10.1016/ S0140-6736(20)30566-3

PMid:32171076

7. Albitar O, Ballouze R, Oi JP, Ghadzi SM. Risk factors for mortality among COVID-19 patients. Diabetes Res Clin Pract. 2020;166:108293. https://doi.org/10.1016/j. diabres.2020.108293

PMid:32623035

8. Wu R, Ai S, Cai J, Zhang S, Qian ZM, Zhang Y, et al. Predictive model and risk factors for case fatality of COVID-19: A cohort of 21,392 cases in Hubei, China. Innovation. 2020;1(2):100022.

9. Ouchetto $O$, Bourhanbour AD. Risk factors of COVID-19 patients. Soc Disaster Med Public Health. 2021;1(1):1-3. https:// doi.org/10.1017/dmp.2021.7

PMid:33413734

10. Melsen WG, Bootsma MC, Rovers MM, Bonten MJ. The effects of clinical and statistical heterogeneity on the predictive values of results from meta-analyses. Clin Microbiol Infect 2013;20(2):123-9. https://doi.org/10.1111/1469-0691.12494 PMid:24320992

11. Sterne JA, Sutton AJ, loannidis JP, Terrin N, Jones DR, Lau J. Recommendations for examining and interpreting funnel plot asymmetry in meta-analyses of randomised. BMJ. 2011;342:d4002. https://doi.org/10.1136/bmj.d4002 PMid:21784880

12. Sedgwick $P$, Marston $L$. How to read a funnel plot in a metaanalysis. BMJ. 2015;351:h4718. https://doi.org/10.1136/bmj. h4718

PMid:26377337

13. Alfhad H, Saftarina F, Kurniawan B. Dampak infeksi SARSCov-2 terhadap penderita hipertensi the impact of SARS-Cov-2 infection on patients with hypertension. Majority. 2020;9(1):1-5.

14. Bienvenu LA, Noonan J, Peter K, Wang X. Higher mortality of COVID-19 in males: Sex differences in immune respone and cardiovascular comorbidities. Eur Soc Cardiol. 2020;116(14):2197-206. https://doi.org/10.1093/cvr/cvaa284 PMid:33063089

15. Berenguer J, Ryan P, Rodríguez-Baño J, et al. Characteristics and predictors of death among 4035 consecutively hospitalized patients with COVID-19 in Spain. Clin Microbiol Infect. 2020;2020:24. https://doi.org/10.1016/j.cmi.2020.07.024
16. Rossi PG, Marino M, Formisano D, Venturelli $F$, Vicentini $M$, Grilli R, et al. Characteristics and outcomes of a cohort of COVID-19 patients in the Province of Reggio. PLoS One. 2020;15(8):e0238281. pone. 0238281

PMid:32853230

17. Yang Q, Zhou Y, Wang X, Gao S, Xiao Y, Zhang W, et al. Effect of hypertension on outcomes of adult inpatients with COVID-19 in Wuhan, China: A propensity score-matching analysis. Respir Res. 2020;21(1):1-9.

18. Alguwaihes AM, Al-Sofiani MA, Megdad M, Albader SS Alsari $\mathrm{MH}$, Alelayan $\mathrm{A}$, et al. Diabetes and Covid-19 among hospitalized patients in Saudi Arabia: A single-centre retrospective study. Cardiovasc Diabetol. 2020;19(1):1-12.

19. Ioannou GN, Locke E, Green P, Berry K, O'Hare AM, Shah JA, et al. Risk factors for hospitalization, mechanical ventilation, or death among 10131 US veterans with SARS-CoV-2 infection. JAMA Network Open. 2020;3(9):e2022310. https://doi.org/ 10.1001/jamanetworkopen.2020.22310 PMid:32965502

20. Xie J, Covassin N, Fan Z, Singh P, Gao W, Li G, et al. Association between hypoxemia and mortality in patients with COVID-19. Mayo Clin Proc. 2020;95(6):1138-47. https://doi.org/10.1016/j. mayocp.2020.04.006 PMid:32376101

21. Roeroe PA, Sedli BP, Umboh O. Faktor risiko terjadinya coronavirus disease 2019 (Covid-19) pada penyandang diabetes melitus Tipe 2. E-CliniC. 2021;9(1):154-60.

22. Zhang $Y$, Cui $Y$, Shen M, Zhang J, Liu B, Dai M. Association of diabetes mellitus with disease severity and prognosis in COVID-19: A retrospective cohort study. Diabetes Res Clin Pract. 2020;165:108227. 10.1016/j.diabres.2020. https://doi. org/108227

\section{PMid:32446795}

23. Li X, Xu S, Yu M, Wang K, Tao Y, Zhou Y. Risk factors for severity and mortality in adult COVID-19 inpatients in Wuhan. J Allergy Clin Immunol. 2020;146(1):110-8. https://doi.org/10.1016/j. jaci.2020.04.006

PMid:32294485

24. Nachtigall I, Lenga $P$, Katarzyna J, Thürmann P, MeierHellmann A, Kuhlen $\mathrm{R}$, et al. Clinical course and factors associated with outcomes among 1904 patients hospitalized with COVID-19 in Germany: An observational study. Clin Microbiol Infect. 2020;26(12):1663-9. https://doi.org/10.1016/j. cmi.2020.08.011

PMid:32822883

25. Kementerian Kesehatan, R. Surat Edaran No. HK.02.01MENKES-295-2020 tentang Klaim Penggantian Biaya Perawatan. pdf. Menteri Kesehatan Republik Indonesia; 2020. p. 1-5.

26. Arifin S. Police Brief: Rekomendasi kebijakan penanganan covid-19 di kalimantan selatan. Univ Lambung Mangkurat. 2020;1(3):14. 